\title{
A Study To Assess The Effectiveness Of Video Teaching Knowledge And Practice Regarding Geriatric Care Among The Caretaker In The Family.
}

\author{
*Aruna Devi. M
}

\section{Abstract:}

Objectives: To evaluate the effectiveness of video teaching among care taker of geriatrics. Methods: Pre experimental (one group pre test posttest) design. Results: The result showed that post-test mean knowledge score was higher (18.4) than the pre-test mean score (10.0) and also post-test practice level was higher (20.8) than the pre-test mean score (11.3). Thus the difference in the level of knowledge and practice was found to be significant at $\mathrm{P}<0.001$ level. Conclusion: It shows that video teaching was effective to improve the knowledge and practice of the caretaker.

Keywords: Video Teaching, Geriatric Care, Caretaker.

\section{INTRODUCTION}

Ageing is inevitable. It is irreversible, progressive and is associated with decline in physical and mental functions ${ }^{1}$. With ageing the individual gradually becomes dependent physically, functionally,socially and economically2. Elders usuallyexhibit multiple health problems with complex interactions. It may cause physical, mental, emotional, and behavioral problems ${ }^{3}$.

\section{STATEMENT OF THE PROBLEM}

"A study to assess the effectiveness of video teaching on knowledge and practice regarding geriatric care among the caretaker in the family residing in Ariyankuppam at Puducherry".

\section{OBJECTIVES OF THE STUDY}

- To assess the knowledge and practice regarding geriatric care among caretaker.
- To evaluate the effectiveness of video teaching among care taker of geriatrics.To associate the level of knowledge and practice among care taker about geriatric care withthe selected demographic variables.

\section{MATERIALS AND METHODS}

RESEARCH DESIGN: Pre experimental (one group pre test post test) design.

STUDY SETTING: The study was conducted in Ariyankuppam (Urban area) at Puducherry.

Population: The population of the study includes all the subjects between the age group of 20 to 40 years at Ariyankuppam.

Sampling Technique: Simple random sampling technique by lottery method was adopted for this study.

\section{Description of Tool}

The data was collected using structured interview questionnaire.

The tool consists of section A, B and C. 


\section{SECTION A}

Deals with demographic variables such as age, religion, educational status, occupation, type of family, monthly family income, area of residence.

\section{SECTION B}

Deals with knowledge regarding geriatric care among caretaker includes 25 statements focusing on knowledge of geriatric care which includes common changes in cardiovascular system, self-care deficit, screening for geriatrics, nutritional needs, daily activities.

\section{SECTION-C}

Deals with practice regarding geriatric care among caretaker includes 10 questions focusing on practice of geriatric care which includes diet, exercise, personal hygiene, normal sleep pattern, health checkup, socialactivity

\section{DATAANALYSIS}

Knowledge level of caretaker regarding geriatric care in pre test and post test programme

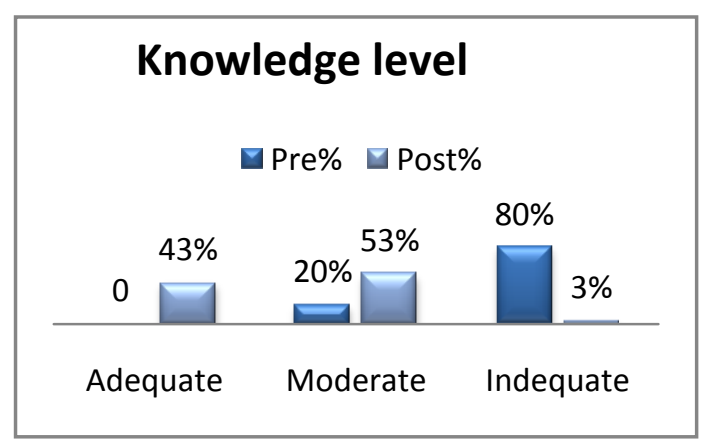

Practice level of caretaker regarding geriatric care in pre test and post test programme

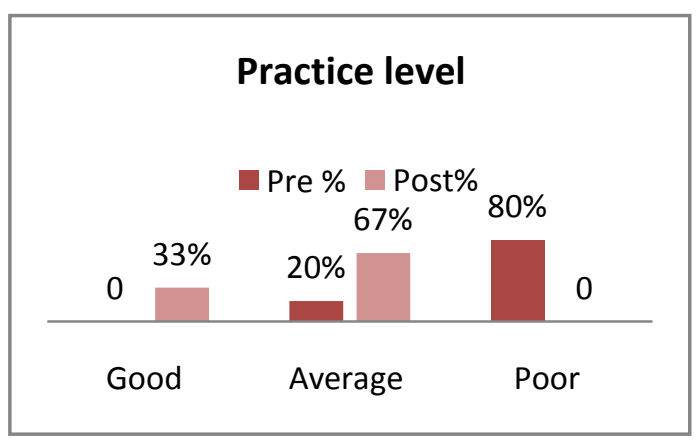

Comparison of the mean pre test and post test knowledge score of the care taker

\begin{tabular}{|l|l|l|l|l|}
\hline Group & Mean & $\begin{array}{l}\text { Std. } \\
\text { Deviation }\end{array}$ & t-value & p-value \\
\cline { 1 - 1 } & 10.0 & 2.391 & \multirow{2}{*}{16.2382} & $* * * 0.0000(\mathrm{~S})$ \\
TEST & 18.4 & 2.176 & & \\
$\begin{array}{l}\text { POST } \\
\text { TEST }\end{array}$ & 176 & & \\
\hline
\end{tabular}

Comparison of the mean pre test and post test practice score of thecaretaker

\begin{tabular}{|l|l|l|l|l|}
\hline Group & Mean & $\begin{array}{l}\text { Std. } \\
\text { Deviation }\end{array}$ & t-value & p-value \\
\hline $\begin{array}{l}\text { PRE } \\
\text { TEST }\end{array}$ & 11.3 & 2.890 & \multirow{2}{*}{14.019} & $0.0000^{* * *} \mathrm{~S}$ \\
\hline $\begin{array}{l}\text { POST } \\
\text { TEST }\end{array}$ & 20.8 & 2.631 & & \\
\hline
\end{tabular}

The result shows that post-test mean knowledge score was higher than the pre-test mean score whereas post-test practice level was higher than the pre-test mean score. Thus the difference in the level of knowledge and practice was found to be significant at $\mathrm{P}<0.000$ level.

\section{DIMITATION}

- The sample size was conducted on small size of 30caretakers.

- The period of study was limited to 1 week.

\section{RECOMMENDATIONS}

- Similar study can be conducted in large samples for broader generalization and frame health promotion incommunity.

- Similar study can be conducted in health professionals.

The comparative study can be done in urbanarea. 


\section{CONCLUSION}

Elderly care has become a growing concern for many families, community and state agencies, and for the many establishments that provide living arrangements for the elderly. "Elderly care" includes nursing care medical attention, often rehabilitation, counselling social services and psychological support. Care in the old age will lead to secure many physical and mentalproblems.

\section{REFERENCES}

1. Bowker LK, price J.D et.al."Geriatric Medicine": 1st Edition, New york. Elesvier Publication;2006. Page no.110.

2. Park. K. "Preventive and Social Medicine": 22nd Edition, New Delhi. M/S BanarsidasBhanot Publisher; 2014. Page no. 455-458.

3. Gulani K. "Community Health Nursing Principles and Practice": 1st Edition, New Delhi; Kumar Publishing House; 2005. Page no:136.

\section{Nine-Point Postpartum Assessment}

\section{BUBBLEHER}

B- Breasts

U- Uterus

B- Bladder

B- Bowel function

L- Lochia

E- Episiotomy

H- Homan's sign

E- Emotional Status

R- Respiratory System 